\title{
Augustine on redemption in Genesis 1-3
}

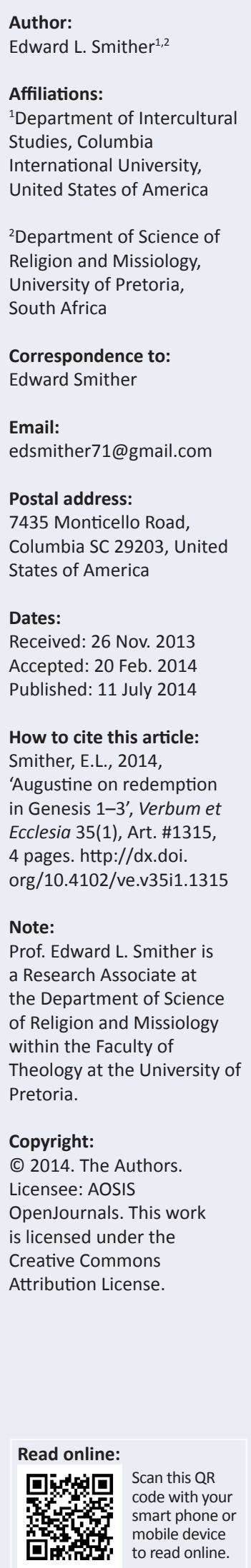

Many theologians, including those concerned with theology of mission, frame the drama of God's story and mission (missio Dei) through the three major acts of creation, fall and redemption. Others add that the new creation ought to be regarded as a fourth act. Although this framework describes the entire biblical narrative, creation, fall and the hope of redemption are, of course, quite present in the first three chapters of Genesis. In this article, I endeavoured to engage with the commentaries of the African church father Augustine of Hippo (354-430 CE) to grasp his thoughts on redemption in Genesis 1-3. In his Genesis works, Augustine was primarily concerned with clarifying the doctrine of creation and, relatively speaking, had far less to say about redemption. That said, Augustine was, quite interested with Scripture's story of redemption in his magnum opus De Civitate Dei [City of God]. Thus, in this article, I explored two major questions: firstly, why did Augustine pay so little attention to redemption in Genesis 1-3? Secondly, how did he articulate and relate redemption in these chapters? It was shown that whilst his primary focus was to articulate creation, his thoughts on redemption were probably limited some because of the insufficiency of his Old Latin Bible translation and perhaps because of other distractions in ministry. Furthermore, it was argued that Augustine's doctrine of redemption was a subset of his discussion on creation - specifically, that the second Adam (Christ) brought new life to God's image bearers affected by the fall of the first Adam.

Intradisciplinary and/or interdisciplinary implications: My aim was to establish Augustine's thoughts on redemption as a point of dialogue for theologians of mission endeavouring to clarify a theology of mission. As most mission theologians do not consult Augustine in their work and as most early Christian scholars do not read Augustine missionally, this study offered fresh insights for both groups of scholars.

\section{Introduction}

Augustine of Hippo (354-430 CE) was as curious as any early Christian exegete about the accounts of creation, fall and redemption within the opening chapters of Scripture (Hill 2004:17-19). This is evidenced through three distinct commentaries that he produced, as well as rich reflection on Genesis in his Confessiones [Confessions], De Civitate Dei [City of God] and also in other works and sermons. Augustine's interaction with Genesis reveals a hermeneutic and approach to the Scripture that varied according to context, including his occasions for writing and his intended audience (Cameron 1999:74-75). Augustine's Genesis writings are further significant because they provide the reader with a 30-year map into his theological development and maturity as an exegete, theologian and pastor (Hill 2004:20-21).

Many theologians, including theologians of mission, frame the drama of God's story and mission (missio Dei) through the three major acts of creation, fall and redemption. Others add that the new creation ought to be regarded as a fourth act (Tennent 2010:159-190,493). Although this framework describes the entire biblical narrative, creation, fall and the hope of redemption are quite present in Genesis 1-3. In his commentaries on the first three chapters of Genesis, Augustine is primarily concerned with grasping creation and, relatively speaking, he has far less to say about redemption. Augustine was, of course, concerned with Scripture's story of redemption, as De Civitate Dei richly attests; however, this was not the African father's priority in his Genesis works. In this article, I will explore two major questions: firstly, why did Augustine seem to pay so little attention to redemption in Genesis 1-3? Secondly, how did he articulate and relate redemption in these chapters? With this inquiry limited to Augustine's noted commentaries, my aim is to establish Augustine's thoughts on redemption as a point of dialogue for theologians of mission endeavouring to craft and clarify a biblical theology of mission.

\section{Survey of Augustine's Genesis commentaries}

Before addressing these two major questions, it would be helpful to set the stage with a brief summary of each of Augustine's Genesis works. Augustine's initial book, De Genesi contra 
Manichaeos [On Genesis: A refutation of the Manichees], was written from Tagaste in 388 and 389 after Augustine had withdrawn with likeminded believers to form a community of servants of God (servi Dei). Intending this as a resource for the church, Augustine employs a thoroughly allegorical hermeneutic to argue against the Manichean view of creation. In particular, he underscores the goodness of creation (Gn 1:31) against the pessimistic Manichean view of it.

From 393-395, whilst serving as a presbyter in Hippo, Augustine worked on his De Genesi ad litteram imperfectus [Unfinished literal commentary of Genesis]. Again, his aim was to serve the church with this work and offer a more literal reading of Genesis. However, he still writes with an apologetic eye toward the Manicheans. As the title suggests, Augustine never completed this project perhaps because of the challenge of writing through a different interpretive lens or because of his increasing pastoral responsibilities. The work is short and only covers Genesis 1. Although Augustine included it in the index of his works compiled toward the end of his life, he urged that it be read in light of his later literal commentary on Genesis.

Augustine's next deliberate commentary on Genesis is housed in the final three books (Books 10-13) of his Confessiones, which was written around 397 during his initial years as bishop of Hippo. Incorporating both an allegorical and literal approach, Augustine only deals with Genesis 1 and his major themes are time, eternity, the work of the Godhead in creation and a discussion of the days of creation.

From 401 to 416, the same period that Augustine was occupied with the Donatists, Pelagius and beginning to write De Civitate Dei, he worked on his De Genesi ad litteram [Literal meaning of Genesis]. In this second literal commentary on Genesis, Augustine simply purposes to refute a false view of Genesis. Shedding some light on his interpretive method, Augustine states that his purpose was to uphold the 'proper literal meaning' unless 'something is said which is taken literally is simply absurd, then undoubtedly it should be understood as being said figuratively in order to signify something more profound' (Gn. litt. 11.1.2). ${ }^{1}$

Finally, in Books 11-14 of De Civitate Dei, Augustine interacted a good bit with Genesis 1-3. As he elaborates on the earthly and heavenly cities, Augustine's concern is to chart their origin, progress and ultimate destinies. For Augustine, the two cities begin with good and fallen angels, which human beings emulate.

\section{Why so little on redemption?}

Why does Augustine give so little space to the theme of redemption in Genesis 1-3? Firstly, his primary interest in reading the early chapters of Genesis was clearly to understand and clarify creation. As shown, his occasion

1.All English translations of Augustine's Genesis works are from E. Hill in the Works of Saint Augustine series (cf. Augustine 2004), except for De Civitate Dei, which is
from M. Dods (cf. Augustine 2009). These works in Latin have been consulted in the from M. Dods (cf. Augustine 2009). These works
Patrologiae Latinae series (cf. Augustine n.d.). for writing De Genesi contra Manichaeos was to correct the Manichean view of creation. As his unfinished literal commentary only addressed Genesis 1, there is little more to discuss than creation. Furthermore, his concerns in Books 10-13 of Confessiones are strongly centred on the doctrine of creation.

Secondly, Augustine did not read portions of Genesis 3 with quite the redemption angle that some ancient and modern scholars have. Let us first consider Genesis $3,{ }^{2}$ which reads:

And they heard the sound of the LORD God walking in the garden in the cool of the day, and the man and his wife hid themselves from the presence of the LORD God among the trees of the garden. But the LORD God called to the man and said to him, 'Where are you?'. (vv. 8-9)

In the mid-3rd century, Novatian (2001) (Trin.1.12) read this to mean:

The fact that God searches for [Adam] does not proceed from any ignorance on the part of God, but it manifests man's hope of a future discovery and salvation in Christ. (pp. 84-85)

A century later, Chrysostom (2001) (Hom. Gen. 17.22) preached from Genesis 3:9 that God:

was not unaware of the truth when he asked them but rather knew ... he shows consideration for their limitations so as to demonstrate his own loving kindness, and he invites them to make admission of their faults. (p. 85)

Some modern theologians of mission regard the Lord's call to Adam as the first concrete evidence of the mission of God - God's own redemptive initiative toward fallen man. Augustine, on the other hand, read Genesis 3:8-9 quite differently. Although concurring with Novatian and Chrysostom that the Lord's question ('where are you?') was not asked in ignorance, Augustine argues that these words were actually 'words of reproof' (Gn. litt. 11.34.45). For Augustine, God's questions were intended to fully expose Adam's pride and sin; so they are more about pronouncing judgement and pointing to the death of Adam's soul than alluding to redemption (cf. Gn. litt. 11.34.47; Civ. Dei 13.23).

Another passage that Augustine interpreted differently was Genesis 3:15, in which the Lord curses the serpent: 'I will put enmity between you and the woman, and between your offspring and her offspring; he shall bruise your head, and you shall bruise his heel.' For Irenaeus (Irenaeus $A H, 5.21$ ), this passage was key to his recapitulation theory of Christ's redemptive work. He writes:

Christ completely renewed all things, both taking up the battle against our enemy and crushing him who at the beginning had led us captive in Adam, trampling on his head, as you find in Genesis that God said to the serpent. (cf. Presley 2012:55-56)

A number of modern scholars join a tradition of scholarship that regards these divine curses as the protoevangelium - the 2.All Scripture references in this article are from the English Standard Version (ESV). 
gospel or redemption declared in the garden in the midst of man's fallenness. For instance, Wayne Grudem (1995) asserts:

Even in the lifetime of Adam and Eve there are some words of God that point toward a future salvation: in Genesis 3:15 the curse on the serpent includes a promise that the seed of the woman (one of her descendants) would bruise the head of the serpent but would himself be hurt in the process - a promise ultimately fulfilled in Christ. (p. 118)

Christopher Wright (2006:212) adds, 'Paul affirms that Jesus, the seed of Abraham, is the one through whom that promise has become a reality' (cf. Erickson 1998:318; Kaiser 2012:16-17).

In general, Augustine read this passage to symbolise humanity's ongoing struggle with the devil. In his allegorical commentary against the Manicheans (Gn. Adv. Man. 2.18.28), he writes that the seed of the devil 'stands for his perverted suggestions', whilst the seed of the woman is 'the fruit of good works that resist those perverted suggestions'. He then summarises:

And this is why he looks out for the woman's heel, in order to catch her if unlawful pleasure creeps in; and she looks out for his head, in order to cut him off at the very beginning of his evil persuasive suggestions. (Gn. Adv. Man. 2.18.28)

Interestingly, later in the completed literal commentary (Gn. litt. 11.36.49), he argues that Genesis 3:15 should be taken figuratively and he reminds the reader of what he had previously written in De Genesi contra Manichaeos.

As Augustine seemed quite committed to Scripture's redemptive narrative, especially in his two cities framework in De Civitate Dei, it seems surprising that he would not read the Genesis 3:15 in light of this overarching narrative. Perhaps the African father was so preoccupied with other matters the Donatists, Pelagius, pastoral challenges - that he chose to allow his earlier allegorical readings of the passage to suffice. Another possible reason why Augustine failed to see the redemptive angle in the text was simply because of how his Old Latin (Vetus Latina) Bible rendered this verse (cf. Metzger 1977:227-230, 2001:30-31).

As the comparison in Table 1 indicates (Vulgata + Vetus Latina 2012), the Old Latin's use of 'watch over' or 'serve' (servo) varied significantly from the Vulgate's 'crush' or 'break' (contero), with regard to what the woman's seed would do to the offspring of the serpent (cf. Gn. Adv. Man. 2.14.20; Gn. litt. 11.2.4; 11.12.16; 11.25.33). Perhaps this less potent word led Augustine to conclude less theologically from this text. It should be noted, however, that Irenaeus also preached in part from a Gallican version of the Old Latin Bible - albeit two centuries before Augustine in Hippo - and his text also uses 'watch over' (observo) as well (Harvey 2013:380-381). Yet, as shown, Irenaeus clearly interpreted this activity as the future work of Christ destroying the works of the devil.

\section{How did Augustine articulate redemption?}

Although Augustine did not read these noted Genesis 3 passages in a particularly redemptive manner, there is still evidence for redemptive thought in his exegesis of Genesis 1-3. Keeping with his general hermeneutic, Augustine's understanding of redemption is framed by his Christological reading of Scripture.

In a broad sense, Augustine in De Genesi contra Manichaeos sketches out redemptive history in the Scriptures by interpreting each day of creation as an epoch within this narrative (Gn. Adv. Man. 1.23.35-24.42). For Augustine, the 5th day signified the growth of the Jews who had rejected Christ. In the midst of this fleshly age - that of the old man - the 6th day represented Christ being born, the gospel being proclaimed to and received by many nations, and the growth of the church amongst Jews and Gentiles (Gn. Adv. Man. 1.23.39-40). The 7th day or age represents the rest that believers will take with Christ from their good deeds ( $G n$. Adv. Man. 1.23.41). In a similar way, Augustine's Confessiones begin with a prayer to find rest in God. However, it is only after Augustine and his readers grasp the magnitude of creation, fall, and restored creation that such a spiritual rest is attainable. Hence, his Genesis reflections in Books 10-13 of Confessiones ought to be read in light of this motif of rest (Hill 2004:15).

Augustine's most profound thoughts on redemption come within his discussion of creation and the relationship between the first Adam and the second Adam. In De Genesi ad litteram, he argued that the Creator God was a Trinitarian God and that the image of God in man reflected this (Gn. litt. 1.6.12; 1.8.14; 3.19.29). Augustine largely understood the image of God to mean that human beings - in contrast to animals - were rational beings (Gn. litt. 3.20.32). He further asserts that the tree of life in the garden represented Wisdom or Christ and, in keeping with his classic view on evil, he argued that the tree of knowledge of good and evil was a privation of goodness. Furthermore, he contrasts the selfwilled and fallen Adam to Christ and his redeeming work - one who was good but experienced evil for fallen sinners. Augustine describes Christ as:

that child who from the nation of Israel, became Emmanuel, Godwith-us, and reconciled us to God, the man who was mediator between men and God, the Word at home with God, flesh at home with us, Word-flesh between God and us. (Gn. litt. 8.14.32)

TABLE 1: The development of Genesis 3:15 from the Old Latin Bible (early 3rd century) to the Latin Vulgate (translated in the late 4th and early 5th centuries).

\begin{tabular}{ll}
\hline Old Latin Bible & Latin Vulgate \\
\hline $\begin{array}{l}\text { Et inimicitias ponam inter te et inter mulierem, et inter semen tuum et semen eius: } \\
\text { ipsa tibi servabit caput, et tu servabis eius calcaneum. }\end{array}$ & $\begin{array}{l}\text { Inimicitias ponam inter te et mulierem, et semen tuum et semen illius: ipsa conteret caput } \\
\text { tuum, et tu insidiaberis calcaneo eius. }\end{array}$ \\
$\begin{array}{ll}\text { And I will put enmity between you and the woman, and between your seed and her } \\
\text { seed; she shall watch over your head, and you shall watch over her heel. }\end{array}$ & $\begin{array}{l}\text { I will put enmity between you and the woman, and your seed and her seed; she shall crush } \\
\text { your head, and you shall lie in wait for her heel. }\end{array}$ \\
\hline
\end{tabular}


Continuing to contrast Christ to Adam, Augustine adds:

The one who did not come to do his own will but the will of the one by whom he had been sent, not like that other one who chose to do his own will ... How right it is that just as through the disobedience of one many have been constituted sinners, so by the obedience of one man shall many be constituted as just'. (Gn. litt. 8.14.31)

In De Civitate Dei, Augustine also contrasts the first Adam with Christ. He asserts that Adam was made a living soul with a physical body; yet, one that could die if he ate from the forbidden tree. Augustine writes:

For certainly on that very day their nature was altered for the worse and vitiated, and by their most just banishment from the tree of life they were involved in the necessity even of bodily death. (Civ. Dei. 13.23.1)

In Confessiones, Augustine reflects on his own sins and the reality of being Adam's offspring:

With all the sins I had committed against you, against myself and against other people, evil deeds many and grievous over and above the original sin that binds all of us who die in Adam. (Conf. 5.9.16)

Whilst the first Adam was created as a living soul, Augustine asserts that " the last Adam was made a quickening spirit", plainly referring to Christ, who has so risen from the dead that He cannot die anymore' (Civ. Dei. 13.23.2). Again, referencing Paul (1 Cor 15:21-22), Augustine summarises the redemption made available through the work of Christ: 'Since by man came death, by Man came also the resurrection of the dead. For as in Adam all die, even so in Christ shall all be made alive' (Civ. Dei. 13.23.3). In summarising Augustine's thoughts on redemption in John's Gospel (In Johannis evangelium tractatus), Finbarr Clancy (1999) succeeds in capturing what Augustine had articulated from Genesis as well. He writes:

The sinless Adam restores the image of God in the first Adam, who lies scattered and broken on the face of the earth ... Linking the themes of creation and redemption, Augustine refers to Christ as 'hominis formator et reformator, creator et recreator, factor et refactor'. (Clancy 1999:702; cf. Jo. Ev. Tr. 10.11; 38.8)

\section{Conclusion}

In this article, I have attempted to locate Augustine's thought on redemption by summarising the chronology and scope of his Genesis commentaries. Whilst redemption seems to be important in Augustine's theology as a whole, I have endeavoured to show why it was not so prominent in his Genesis works. This seems largely because of the occasions and audiences for his writing and that clarifying the doctrine of creation was his primary concern. As it has been shown, however, Augustine did talk about redemption, just not in the places in Scripture where other ancient and modern commentators have - namely Genesis 3. Rather, Augustine articulated his thoughts on redemption within his thoughts on creation, especially the creation of man who bears God's image. Furthermore, Augustine spoke of redemption most when contrasting the person and work of the second Adam who offers life to those who have died in the first Adam.

As theologians of mission seek to grasp redemption within the broader biblical framework, Augustine's reflections on Genesis 1-3 provide a point of departure for further reflection. In particular, it seems worthwhile to think about redemption as the opportunity for fallen men and women bearing the image of God to be restored as new creations in Christ. In this way, Augustine does not see the need to wait until the fall narrative of Genesis 3 to begin discussing redemption and new creation; rather, he relates redemptive thought from Genesis 1. Ultimately, Augustine employs a Christo-centric hermeneutic and theology where Christ is simultaneously creator and (as the second Adam) re-creator. Whilst Augustine's thought has been established, this study has prompted at least two questions for further study: how does Augustine's Christological framing of redemption affect how we think about mission? How does it affect how we communicate the gospel?

\section{Acknowledgements Competing interests}

The author declares that he has no financial or personal relationships that may have inappropriately influenced him in writing this article.

\section{References}

Augustine, n.d., Opera Omnia (Complete Latin Works), Patrologiae Latinae, viewed 25 November 2013, from http://www.augustinus.it/latino/index.htm

Augustine, 2004, On Genesis: On Genesis: A refutation of the Manichees, Unfinished litera commentary on Genesis, The literal meaning of Genesis (Works of Saint Augustine, a translation for the 21st century), transl. E. Hill, New City Press, Hyde Park.

Augustine, 2009, The City of God, transl. M. Dods, Hendricksen, Peabody.

Cameron, M., 1999, 'The Christological substructure of Augustine's figurative exegesis', in P. Bright (ed.), Augustine and the Bible, pp. 74-103, University of Notre Dame Press, Notre Dame.

Chrysostom, 2001, Homilies on Genesis, in A. Louth (ed.), Ancient Christian commentary of Scripture 1 (Genesis 1-11), p. 85, Intervarsity Press, Downers Grove.

Clancy, F., 1999, 'Redemption', in A. Fitzgerald (ed.), Augustine through the ages: An encyclopedia, pp. 702-704, Eerdmans, Grand Rapids.

Erickson, M., 1998, Christian theology, Baker Academic, Grand Rapids.

Grudem, W., 1995, Systematic theology: An introduction to biblical doctrine, Zondervan, Grand Rapids.

Harvey, W.W., 2013, Saint Irenaeus, bishop of Lyons' Five books against all heresies: Greek and Latin edition, vol. 2, Create Space.

Hill, E., 2004, 'General introduction', in Augustine (ed.), On Genesis: On Genesis: A refutation of the Manichees, Unfinished literal commentary on Genesis, The literal meaning of Genesis (Works of Saint Augustine, a translation for the 21st century) transl. E. Hill, pp. 13-20, New City Press, Hyde Park.

Irenaeus, 2001, Against all heresies, in A. Louth (ed.), Ancient Christian commentary of Scripture 1 (Genesis 1-11), pp. 90-91, Intervarsity Press, Downers Grove.

Kaiser, W., 2012, Mission in the Old Testament: Israel as a light to the nations, Baker Academic, Grand Rapids.

Metzger, B., 1977, The early versions of the New Testament: Their origin, transmission, and limitations, Baker Academic, Grand Rapids. http://dx.doi.org/10.1093/acprof:0 so/9780198261704.001.0001

Metzger, B., 2001, The Bible in translation: Ancient and English versions, Baker Academic, Grand Rapids.

Novatian, 2001, On the Trinity, in A. Louth (ed.), Ancient Christian commentary of Scripture 1 (Genesis 1-11), pp. 84-85, Intervarsity Press, Downers Grove.

Presley, S., 2012, 'The lost sheep who is found: Irenaeus' intertextual reading of Genesis 3 in Adversus Haereses 3.23.1-8', Studia Patristica 52, 47-59.

Tennent, T., 2010, Invitation to world missions: A Trinitarian missiology for the twentyfirst century, Kregel Academic, Grand Rapids.

Vulgata + Vetus Latina, 2012, Geneis 3:15, viewed 14 October 2013, from http://vulgate. net/vt/gn3-15

Wright, C., 2006, The Mission of God: Unlocking the Bible's grand narrative, Intervarsity Press, Downers Grove. 